\title{
The Effectiveness Of Teachers' Professionalism Development Management By Local Government
}

\author{
Aty Susanti \\ Education Administration of Postgraduate Studies \\ Indonesia University of Education \\ Bandung, Indonesia \\ sanbrelle@gmail.com
}

\begin{abstract}
The main aim of the study is to analyze the effectiveness of the management of teacher professional development in Bogor district that includes: need analysis and designing an alternative model of effectiveness of teachers professional development to local governments in accordance with the provisions of the legislation. The research method used was a qualitative method. Qualitative research approach used is a case study; the process data collection is done through in depth interview and documentation. Determination of the respondents was purposively sampled and snowballs. Respondent are Dinas Pendidikan, Badan Kepegawaian Pendidikan Pelatihan (BKPP), Principal and Teachers in Bogor District. The result showed the essential findings related to analysis of the need for teacher professional school does not yet include the conditions detailed school. So, need for improvement in teachers development program.
\end{abstract}

Keywords-effectiveness, teachers profesionalism development management

\section{INTRODUCTION}

In the era of regional autonomy, the management of education is carried out autonomously by local government district / city, ranging from planning, organizing, implementing, up to evaluation and development. In this context, the role of local government district / city management focuses on developing education management professionally, including programs increasing teacher professionalism. According to the Lembaga Pusbang Prodik Kemdikbud (2014), the number of training after decentralization is held much less frequent by local governments. It can be observed that elementary school education relatively contains more problems than junior and senior high schools education.

Based on empirical phenomenon, the state of education in Indonesia today, related to the teacher competence of elementary schools is no better than the teacher competence of kindergarten (TK). The low competence of teachers which could affect the quality of elementary educational services is common among teacher of lower classes or grade 1-3. The competence of middle and high school teachers is in better condition than elementary school and kindergarten teachers. Based on the results of early competency tests (UKA) which was used to select teachers who could participate in teacher certification quotas in 2012 nationally through education and training of the teaching profession (PLPG), the competence of elementary teachers were the lowest compared to the teachers of other levels, even below kindergarten teachers.

Furthermore, the average competency of elementary school teachers is 36.85 , while the average competency of kindergarten teacher is 58.87. The average UKA of junior high school teachers is 65.2 and high school teachers is 83.4. The results of teacher competency test (UKG) followed by certified elementary school teachers, also showed that elementary school teachers competence remained the lowest. Pedagogical competence average of elementary school teachers is 42.10 , whereas the average of kindergarten teachers is 44.31. Professional competence average of elementary teachers is 41.26, while the average of kindergarten teachers is 45.77 . The average score of UKG followed by junior high school teachers is 46.1 whereas the average score of high school and vocational school teachers is 51.3 and 50.0. Overall, the average result of UKG ranging from kindergarten through high school teachers was 44.5 (quoted from kompas.com [4.8.12] and [9.6.12].

One district in West Java which consistently implements teacher professionalism development program is Bogor. Data from Education Department of Bogor District (2014) shows that the government of Bogor District has conducted various efforts to improve the quality of education. These efforts are based on the strategic issues of education in Bogor District, which includes the low average length of finishing school (RRLS), dissemination of educational facilities that are not evenly distributed, the considerable number of classrooms that are in severely damaged condition, the limited number of high quality schools, the poor quality of graduates, the unbalanced needs of educators (teachers) and teachers, the uneven number of professional, qualified and competent teachers, and the implementation of Curriculum 2013.

As for the conditions of elementary, junior high and high school teachers in Bogor based on their educational background in the academic year 2013/2014, the number of undergraduate teachers is not yet fully in accordance with the expectations of the education office which is $100 \%$ with professional capability above $80 \%$. In addition to the level and appropriateness of education, the distribution of professional teachers is uneven. Professional teachers are spread in several areas close to the center of cities. Schools in areas far from 
urban areas do not have any professional teachers and even the ratio number of teachers who teach with schools is very low (Bogor District Education Profile 2013-2014).

Based on observation results and documentation study, the problems of the quality of teachers in the Bogor District were then obtained, namely (1) the lack of sufficient knowledge (didactic, methodical, material) and creativity in learning; (2) the lack of career opportunities that encourage achievement motivation; (3) the lack of evaluation and monitoring of the implementation and impact of upgrading or teachers training, particularly at the school level.

According to Castetter (1996, p 236), the process of teacher development in an educational system includes four phases, namely phase (1) diagnosing development needs, (2) designing development plans, (3) implementing development programs, and (4) evaluating programs. In reality, each of those phases would only be done with macro and not very detailed assessment. During the training process organized by the district government of Bogor, in some places it is known that instead of becoming the subject, the training process puts teachers more as objects in learning about professionalism.

Based on the background of the problems, the main issues studied in this study is: How is the need analysis for teacher professional development done by Education Department of Bogor district government?

This research is conducted with the aim to :Describe the need to analyze the teacher professional development done by Education Department of Bogor district government

\section{Research Problem}

1.How is the need analysis for teacher professional development done by Education Department of Bogor district government?

\section{RESEARCH Methodology}

Based on the formulation of research problems, research objectives, the context of the research, the characteristics of the collected data, as well as descriptions and explanations of several experts on qualitative methods and case study approach

\section{Research Population and Sample}

Determination of the respondents was purposively sampled and snowballs. Respondent are Dinas Pendidikan, Badan Kepegawaian Pendidikan Pelatihan (BKPP), Principal and Teachers in Bogor District

\section{RESULT AND REFLECTION}

\section{Needs Analysis of Teacher Development Program}

According to the result of research, mapping of the problem is still limited. There are no mapping problems yet either based on the structure of problems (simple, rather complicated or complicated) as well as level of problems in teacher development (individual level, schools level, policy level such as the weak incentive system for professional teachers). The development of teacher development programs has not included in-depth study of problems identification.

Implementation of teacher professionalism training which understand the compatibility of professionalism development education and district government strategy to achieve the vision and mission of Bogor district is still limited. Activities on the functional level are not as strategic activities.

According to the result of research, The demands on the quality of educators in Bogor Regency is a manifestation of their understanding and awareness to achieve quality in education through improving the quality of teachers as educators although it is still limited in quantity. The quality of teachers has not been a major focus in the implementation of teacher professionalism development compared to the quantity. This can be seen from the not yet optimum process of realizing the professionalism of the professional competence after the training particularly on action research, the ability to master the subject matter widely and deeply is still limited. This is due to the lack of teacher interest in optimizing the use of reference to develop teaching skills as well as the concept development.

Empirical facts after the teacher professionalism training are not in line with Parker et al (2011) who confirm that the development of teachers should be based on a flexible HR management platform and information systems, which can facilitate the adequacy and fairness and support for teacher development. The adequacy and fairness and support for teacher development are still limited to training. Application in practice has not yet fully supported for example by scientific references to carry out action research, which is still low. Only a few schools provide learning resources / references for teachers to do research or to develop models of learning as a result of professional training. The information system for applying the results of training in the workplace is still limited.

In reality, the paradigm that human resources development is the realization of the position human resource management as a strategic partner has not yet formed. Most of the organizers of the human resources development view that it is an activity intended to meet the administrative needs or just to meet daily operational activities at the school. In accordance with the results of research conducted by Onchwari \& Kenge (2008) in their research on initiative based human resource development practices as a mentor showed that the practice is effective in improving the quality of teaching practices. These results indicate that the training was based on the need for mentors to become professional. Considerations in the delivery of training is the need of mentors especially for novice teachers. Training should be able to increase initiatives for experienced teachers to provide mentoring. The initiative is rarely grown in the training. District government should foster the need to take the initiative for teachers who have completed their training and obtained certificates. 


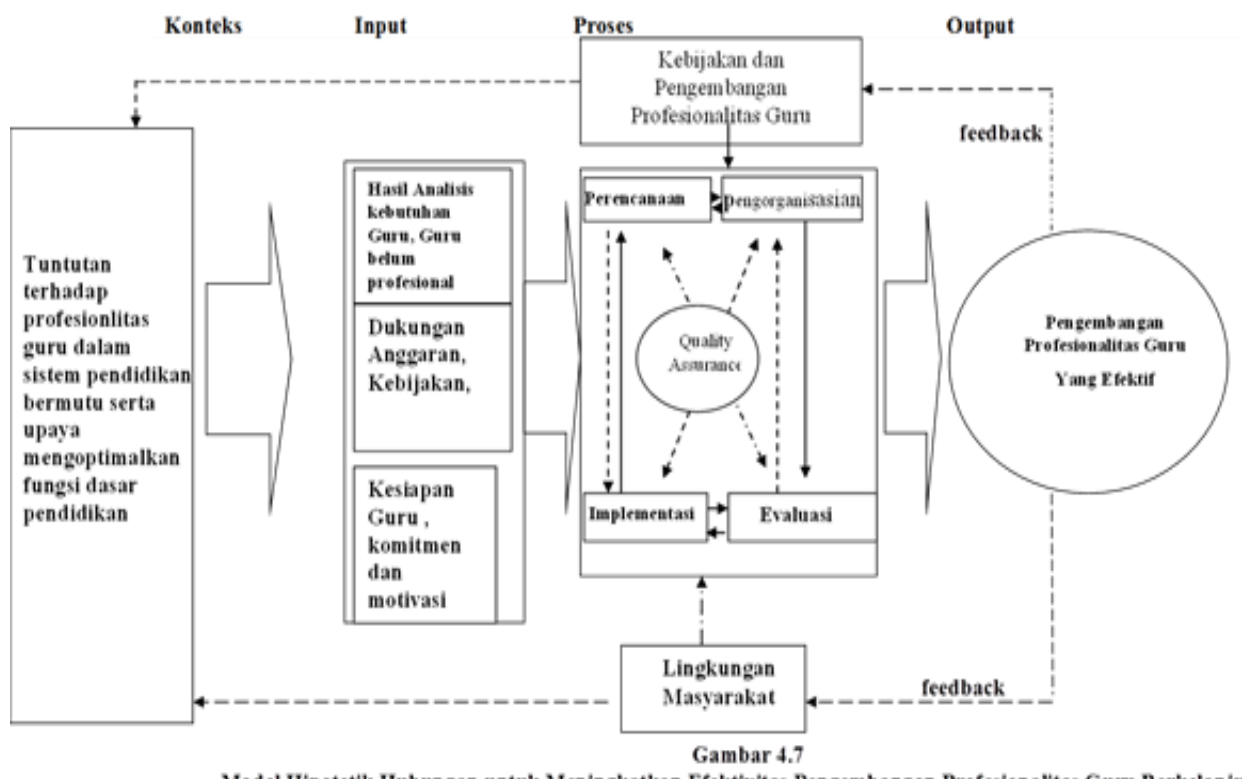

Model Hipotetik Hubungan untuk Meningkatkan Efektivitas Pengembangan Profesionalitas Guru Berkelanjutan

\section{CONCLUSION \& RECOMMENDATION}

This study examined the Effectiveness of Teacher Professionalism Development Management by Local Government, a case study in Bogor District. In general, we can conclude that the management of teacher professionalism development in Bogor District is not yet effective, as measured by the management of teacher professionalism development with objective criteria for effective management. When measured properly with the criteria of the process and criteria of the stages of human resource development namely need analysis.

Further research is needed to test the management model of teacher professionalism development with a focus on forms of teacher professionalism development for school teachers and their effectiveness for schools in accordance with the category.

\section{REFERENCES}

[1] Berg, Bruce L. 2007. Qualitative Research Methodes for The Social Sciences. Boston: Pearson education. Inc.

[2] Castetter (1996). The Human Resource Function in Educational Administration. New Jersey, hlm 236

[3] Creswell, J. W. (2003). Research Design Qualitative, Quantitative and Mixed Methods Approaches (2th ed). Thousand Oaks, California: SAGE Publications, Inc. Tersedia:http://www.uc.ac.id/.[6 April 2012].

[4] Noe, R.A, Hollenbeck, J.R, Gerhart, B. \& Wright, P.M. (2010).Human Resources Management: Gaining Competitive Advantage. (4thed.). New York: Irwin/McGraw-Hill.

[5] Parker, D., Mahomed, H., Geyer, S. \&Modise, G. (2011). Integrated Strategic Planning Framework for Teacher Education and Development in South Africa, Teacher Development, 5 April 2011.

[6] Sambrook, J. dan Stewart,S (2007). Human ResourceDevelopment inthe Public Sector. NY. Routledge.F. Tjiptono, Pemasaran Jasa. Malang: Bayumedia Publishing, 2005

[7] Pusbang Prodik Kemdikbud (2014). Profesionalitas guru di era otonomi daerah

[8] Satori, D. dan Komariah, A. (2009). Methodology Penelitian Kualitatif. Bandung;Alfabeta.K. C. Laundon, J. P. Laudon, Sistem Informas Manajemen: Mengelola Perusahaan Digital: edisi 13 (terjemahan). Jakarta: Salemba empat, 2013

[9] Onchwari, G. danKeengwe, J (2008). The Impact of a Mentor-coaching Model on Teacher ProfessionalDevelopment.Early Childhood Educ Journal (36) hlm 19-24. 